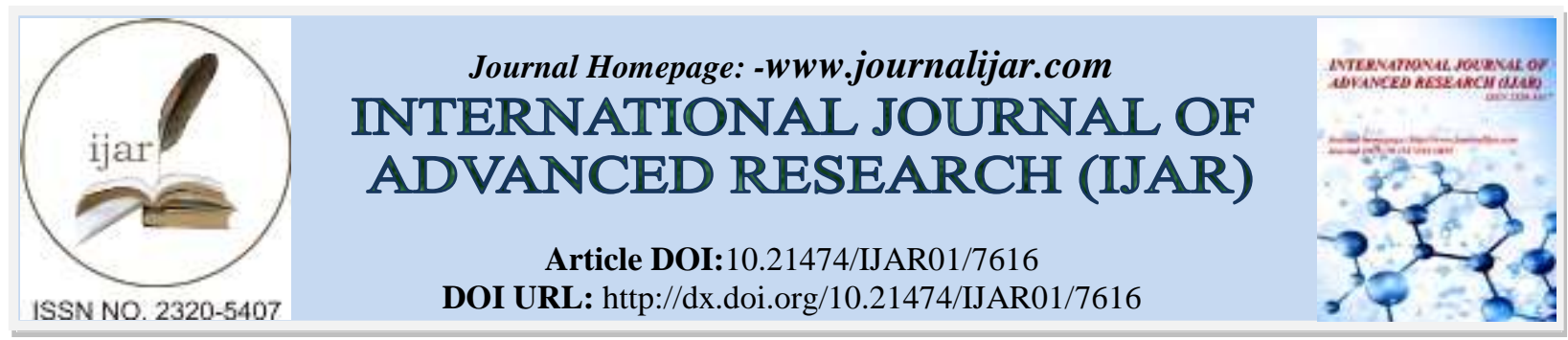

RESEARCH ARTICLE

\title{
STUDIES ON COMPOSTING OF COCOA (THEOBROMA CACAO L.) POD HUSK.
}

\section{Praveena ${ }^{1}$, J. Suresh ${ }^{1}$, V. Jegadeeswari ${ }^{1}$, J. Kannan ${ }^{2}$ and S. Karthikeyan ${ }^{3}$.}

1. Department of Spices and Plantation crops, Tamil Nadu Agricultural University, Coimbatore -641003.

2. Department of Environmental Sciences, Tamil Nadu Agricultural University, Coimbatore - 641003.

3. Department of Agricultural Microbiology, Tamil Nadu Agricultural University, Coimbatore - 641003.

\section{Manuscript Info}

Manuscript History

Received: 22 June 2018

Final Accepted: 24 July 2018

Published: August 2018

Keywords:-

Cocoa pod husk, cocoa pod husk

compost, Phanerochaete,

decomposition.

\section{Abstract}

Field experiment was carried out to standardize the protocol for effective decomposing of cocoa pod husk. For these, the experiment comprise of five treatments: cowdung slurry, earthworms, TNAU Biomineralizer, Phanerochaete chrysosporium and Pleurotus sajorcaju. Data on temperature, $\mathrm{pH}$, electrical conductivity (EC), organic carbon, total nitrogen, carbon: nitrogen ratio, total phosphorus and total potassium were analyzed. The experiment was laid out in a Randomized Block Design (RBD) with four replications. The cocoa waste imposed with chrysosporium and Pleurotus sajor-caju showed the rapid decomposition rate than compared with other treatments used in the experiment. The nutrient content of $\mathrm{N}, \mathrm{P}, \mathrm{K}$ were found to be more in the treatment with TNAU Biomineralizer followed by Phanerochaete chrysosporium and Pleurotus sajor-caju.

Copy Right, IJAR, 2018,. All rights reserved.

\section{Introduction:-}

Cocoa belongs to the genus Theobroma, a group of small trees which is native to Amazon and other tropical areas of South and Central America. Cocoa is the third important beverage crop next to coffee and tea. It is the third highest traded commodity in the world after coffee and sugar. The fruit of the cocoa is an important commodity because of the economic value of its beans. Commercial cultivation of cocoa started in India during 1970. Cocoa (Theobroma cacao L.) is mostly grown as intercrop crop in coconut and arecanut gardens in India.

At present, cocoa is grown in four major states of Kerala, Karnataka, Andhra Pradesh and Tamil Nadu. It has great potential for cultivation in other states as well where coconut and arecanut are grown. It occupies an area of 78,000 ha with production of $16,100 \mathrm{MT}$ and the average productivity is $200 \mathrm{~kg}$ per ha. Crop production has increased from 6,700 MT (1993-94) to 16,100 MT (2014-15) (www.indiastat.com).

Cocoa pod husk (CPH), which forms over $70 \%(w / w)$ of the whole matured cocoa fruit, is a major by-product from the cocoa industry but is currently under-utilised. Thus at every cocoa harvesting season, enormous quantities of $\mathrm{CPH}$ become available but discarded as 'waste'. For each ton of dry beans produced, ten tons of cocoa pod husks are generated, which presents a serious challenge for waste management (Figueira et al., 1993).

The present investigation was carried out with the objective to increase the soil fertility in the intercropped cocoa plantation and faster the rate of decomposition with the generation of nutrient- enriched compost from cocoa pod husk. 


\section{Materials and Methods:-}

Field experiment ware carried out at VSR farms, Pollachi, Coimbatore district during 2015-2016. Main materials used were cocoa pod husk, cowdung slurry, earthworms, TNAU Biomineralizer, Phanerochaete chrysosporium and Pleurotus sajor-caju. The cocoa pod husk collected from the processing yard after beans were extracted and dried leaves were collected from the field were used as substrates or raw material for composting process . Composting method used for the experiment was aerobic composting. The treatment datails were, $\mathrm{T}_{1}$ (Cocoa pod husk + cow dung slurry), $\mathrm{T}_{2}$ (Cocoa pod husk + Earthworm), $\mathrm{T}_{3}$ (Cocoa pod husk + TNAU Biomineralizer), $\mathrm{T}_{4}$ (Cocoa pod husk + Phanerochaete chrysosporium $)$ and $\mathrm{T}_{5}($ Cocoa pod husk + Pleurotus Sajor-Caju $)$ and the similar treatments were followed in case of composting of cocoa pod husk. The CPH was chopped into smaller pieces before composting to reduce the particle size. The temperature, $\mathrm{pH}$ and $\mathrm{EC}$ of each pile was monitored for four weeks interval until the end of the composting with the use of digital thermometer. The mixtures were turned every fortnight and watered. The organic materials were composted for four months after which they were allowed to cure for two weeks, shredded and bagged for use. At maturity of the composts, samples were randomly taken from each compost type, milled, sieved through a $2 \mathrm{~mm}$ sieve and subjected to chemical analysis.

The following analyses were carried out at the end of each of the incubation period. $\mathrm{pH}$ and EC were determined in water (1:2 soils: water ratio) and measured in digital meter (Jackson, 1973). Organic carbon was determined by the method of chromic acid wet digestion (Walkely and Black, 1934). Mineralized total Nitrogen was determined by Kjedahl method (Bremner and Mulvaney, 1982), mineralized available P was extracted from the incubation samples using Bray P method (Olsen et al., 1954) and mineralized $\mathrm{K}$ was extracted with $1 \mathrm{~N}$ ammonium acetate at neutral $\mathrm{pH}$ and the amount of $\mathrm{K}$ were determined using flame photometer (Jackson, 1973). The data obtained from the above experiments were analysed using Randomized block design (RBD) as suggested by Panse and Sukhatme (1961). The critical difference was worked out at five per cent probability level and the results were interpreted.

\section{Result and Discussion:-}

All the composts appeared to be granular and dark grey in colour at 120 days of composting. Although colour and dour are the simplest criteria to evaluate the maturity and stability of the compost but for confirmation some physical, chemical and biological parameters were also studied.

\section{Temperature:-}

Changes in temperature at various stages of decomposition of different composting mixtures. Temperature of all the composts reached maximum $\left(56.9^{\circ} \mathrm{C}-62.0^{\circ} \mathrm{C}\right)$ at 30 days of composting in cocoa pod husk and it reflected the rapid initiation of composting process and it decreased gradually but remained in thermophilic range $\left(>40{ }^{\circ} \mathrm{C}\right)$ up to 60 days. It further decreased and reached ambient level between 90 and 120 days of composting in all the treatments and Maximum days of highest temperature was noted in cocoa pod husk treated with Phanerochaete chrysosporium $\left(\mathrm{T}_{4}\right)$ and Pleurotus sajor-caju $\left(\mathrm{T}_{5}\right)$. In general, temperature decreased after each turning indicating decrease in easily decomposable organic matter. Therefore, turning of pile, maintenance of moisture at optimum level and addition of easily available carbon sources are necessary to enhance microbial activity during composting (Tiquia et al., 1997). The compost indicates a good degree of stability when temperature during composting approaches the ambient level (Satisha and Devaranjan, 2007). All the composts attained ambient temperature at 120 days indicating compost stability.

pH:-

The $\mathrm{pH}$ is a good indicator to determine the maturity of compost. The initial $\mathrm{pH}$ ranged between 7.68 to 7.90 for various treatments in cocoa pod husk. The compost $\mathrm{pH}$ is a good indicator of compost maturity. During the initial days of composting, it descends slightly to maintain high $\mathrm{pH}$ and later decreases as the material gradually decomposes and stabilities, finally staying between 6.00 and 7.00 (Cardenas and Wang 1980). The $\mathrm{pH}$ values were significantly $(\mathrm{P}<0.05)$ decreased with the increase of days in all the treatments (Table 1$)$.

\section{Electrical conductivity:-}

The treatment of $\mathrm{T}_{4}$ had shown lowest EC $1.50 \mathrm{dSm}^{-1}$ was recorded in the treatment $\mathrm{T}_{1}$ in cocoa pod husk at 30 days after decomposting. The EC is the measure of a solution's ability to carry out electrical changes that is the measure of a soluble salt content of the compost. It is reported that the salt content of the compost is due to the presence of $\mathrm{Na}, \mathrm{Cl}_{2}, \mathrm{~K}, \mathrm{NO}_{3}$, sulphate and ammonia salts (Brinton 2003). The EC of the compost samples significantly ( $\left.\mathrm{p}<0.05\right)$ varied 0.95 to $1.14 \mathrm{dSm}^{-1}$ respectively in cocoa pod husk was observed in 120 days old compost with lowest EC 
value recorded in $\left(\mathrm{T}_{4}\right)$ cocoa pod husk treated with Phanerochaete chrysosporium. The high value of EC was due to the effect of concentration of salts as a consequence of degradation of organic matter (Campell et al., 1997). While considering the statement of (Brinton 2003) and (Campell et al., 1997), it could be inferred that the cocoa waste in all the treatments attained full maturity and the end product, bio-compost is abundant in various salts for carrying electrical charges and withholding nutrient ions. The EC values of compost from different treatments had shown that the matured compost could be effectively used as valuable manure (Table 1).

\section{Organic Carbon:-}

The organic matter loss increased with composting time in all the composts due to greater availability of easily biodegradable substances to microbes (Benito et al., 2003). Highest losses of organic matter were observed during first 60 days of composting in all the composts which slowed down thereafter. Maximum losses $(21.10 \%)$ of organic matter were observed in cocoa pod husk treated with Phanerochaete chrysosporium $\left(\mathrm{T}_{5}\right)$ followed by Pleurotus sajor-caju $(21.80 \%)\left(\mathrm{T}_{5}\right)$, earthworms $(22.80 \%)\left(\mathrm{T}_{2}\right)$, TNAU Biominerlizer $(24.60 \%)\left(\mathrm{T}_{3}\right)$ and cow dung slurry $(25.50 \%)$ compost $\left(\mathrm{T}_{1}\right)$. This fact indicates that the addition of fungal culture enhanced the decomposition rate of organic matter. The organic matter loss $>42 \%$ may be accepted as an index value for mature compost. The initial nitrogen content varied between $0.45 \%$ to $0.76 \%$ in cocoa pod husk respectively. It was significantly increased $(\mathrm{P}<0.05)$ and attained maximum value on the 120th day. The statement of Gaur (1982) that the macro and micro nutrients were increased during composting due to the loss of organic carbon content as $\mathrm{CO}_{2}$. The breakdown of complex organic compounds into simpler compounds due to bio-degradation and conversion of carbon into $\mathrm{CO}_{2}$ and other by products increased the total nitrogen content in the final matured compost in case of all the five treatments.

\section{Total Nitrogen:-}

The nutrient nitrogen is required for the growth and development of plants and the compost manure obtained from the treatment $\mathrm{T}_{3}$ had a total nitrogen content of $2.21 \%$ and $1.87 \%$ showing that the bacteria played an effective role in the decomposition process while compared to the total nitrogen content of the samples taken from the other four treatments (Table 2).

\section{Carbon/Nitrogen ratio:-}

As the C:N ratio is widely used as an indicator of compost maturity (Bernal et al., 1998). The C:N ratio of all the compost mixtures decreased substantially till 120 days, and stabilized thereafter. As the decomposition progressed due to losses of carbon mainly as carbon dioxide, the carbon content of the compostable material decreased with time and $\mathrm{N}$ content per unit material increased which resulted in the decrease of $\mathrm{C}: \mathrm{N}$ ratio. The cocoa waste composts showed more rapid decrease in $\mathrm{C}: \mathrm{N}$ ratio than the farm waste compost. Addition of agro-industrial wastes as organic additives might have helped in increasing biological activity. At 120 days of composting, highest C:N ratio (15.27) was recorded in cowdung slurry $\left(\mathrm{T}_{1}\right)$ followed by earthworm $\left(\mathrm{T}_{2}\right)(13.49)$, TNAU Biominerlizer $\left(\mathrm{T}_{3}\right)$ (13.16), Pleurotus sajor-caju $\left(\mathrm{T}_{5}\right)$ (12.60) and Phanerochaete chrysosporium $\left(\mathrm{T}_{4}\right)$ ( 11.79) were registered in cocoa pod husk. Previous researchers reported that a $\mathrm{C}: \mathrm{N}$ ratio below 20 was assumed to be indicative of maturity compost (Golueke, 1981), and a ratio of 15 or less is preferable (Morel et al., 1985; Bernal et al., 2009). By considering this criterion, and Phanerochaete chrysosporium $\left(\mathrm{T}_{4}\right)$, Pleurotus sajor-caju $\left(\mathrm{T}_{5}\right)$ and TNAU Biominerlizer $\left(\mathrm{T}_{3}\right)$ composts showed their maturity at 120 days (Table 2).

\section{Total phosphorus:-}

The observations made on total phosphorus during decomposition of cocoa waste showed that there had been gradual increase in total phosphorus from the initiation of study till completion and it was significant at $\mathrm{P}<0.05$ level. The initial concentration of phosphorous varied between $0.43 \%$ in $\mathrm{T}_{1}$ and $0.66 \% \mathrm{~T}_{4}$ were observed in cocoa pod husk after 30 days of composting. The change in phosphorus content during the course of decomposition process is agreeable with the findings (Elango et al., 2009). The highest concentration of total phosphorus $(1.21 \%$ in cocoa pod husk) in the compost obtained from the treatment $\mathrm{T}_{3}$ (TNAU Biominerlizer) had shown that this has highest efficiency in bringing the decomposition of cocoa pod husk and mineralization of organic phosphorus when compared to other treatments used for composting (Table 3).

\section{Total Potassium:-}

The potassium is a valuable plant nutrient which is immobilized in organic matter. During the bio- degradation of organic matter, the potassium is liberated and the end product of the bio-compost contains potassium in the available form composting (Table 3). Potassium is highly soluble in nature and its concentration increases with progressing 
of decomposition (Gallando and Nogales 1987). The concentration of total potassium set a slow and steady increase significantly $(\mathrm{P}<0.05)$ in case of all the five treatments while the decomposition had been progressing and attained stable values on completion of decomposition. The experimental results in this study were found to have similarity with the findings of Gallando and Nogales 1987.

\section{Conclusion:-}

The decomposition of cocoa pod husk helps to produce large quantity of good quality compost, which can be effectively used in field as a fertilizer, thereby the pressure on chemical fertilizers for various farming activities can be reduced and good quality of products free from chemical residues can be produced. Out of various organisms used for decomposing cocoa wastes and application of those composts in crop production had shown that promising results could be obtained from the application of compost produced by Phanerochaete chrysosporium and Pleurotus sajor-caju.

\section{Acknowledgement:-}

We acknowledge the technical and financial support of the Tamil Nadu Agricultural University, Coimbatore, Mondelez International Foods Private Limited and Microbial Type Culture collection (MTCC) IMPECH, Chandigarh.

Table 1:-Changes in temperature, $\mathrm{pH}$ and $\mathrm{EC}$ values during composting of cocoa pod husk

\begin{tabular}{|c|c|c|c|c|c|c|c|c|c|c|c|c|}
\hline \multirow{3}{*}{\begin{tabular}{|cc} 
I. & TREATM \\
ENTS &
\end{tabular}} & \multicolumn{4}{|c|}{ Temperatures $\left({ }^{\circ} \mathrm{C}\right)$} & \multicolumn{4}{|l|}{$\mathrm{pH}$} & \multicolumn{4}{|c|}{$\mathrm{EC}\left(\mathrm{dSm}^{-1}\right)$} \\
\hline & \multicolumn{4}{|c|}{ Sampling periods (Days) } & \multicolumn{4}{|c|}{ Sampling periods (Days) } & \multicolumn{4}{|c|}{ Sampling periods (Days) } \\
\hline & 30 & 60 & 90 & 120 & 30 & 60 & 90 & 120 & 30 & 60 & 90 & $\mathbf{1 2 0}$ \\
\hline $\mathrm{T}_{1}$ & 56.9 & 41.8 & 31.6 & 25.4 & 7.89 & 7.62 & 7.29 & 7.11 & 1.73 & 1.60 & 1.28 & 1.14 \\
\hline $\mathrm{T}_{2}$ & 62.0 & 45.6 & 33.7 & 22.7 & 7.72 & 7.56 & 7.24 & 7.09 & 1.56 & 1.33 & 1.20 & 1.03 \\
\hline $\mathrm{T}_{3}$ & 59.8 & 39.8 & 30.9 & 23.5 & 7.90 & 7.59 & 7.22 & 7.05 & 1.61 & 1.47 & 1.13 & 0.99 \\
\hline $\mathrm{T}_{4}$ & 60.5 & 48.9 & 42.4 & 25.8 & 7.74 & 7.50 & 7.17 & 6.99 & 1.50 & 1.36 & 1.18 & 0.95 \\
\hline $\mathrm{T}_{5}$ & 58.9 & 43.5 & 30.9 & 28.3 & 7.68 & 7.54 & 7.19 & 7.00 & 1.56 & 1.23 & 1.16 & 1.08 \\
\hline
\end{tabular}

Table 2:- Changes in organic carbon content, total nitrogen and C:N ratio during composting of cocoa pod husk

\begin{tabular}{|c|c|c|c|c|c|c|c|c|c|c|c|c|}
\hline \multirow[t]{3}{*}{$\begin{array}{l}\text { II. TREAT } \\
\text { MENTS }\end{array}$} & $\begin{array}{l}\text { Organic } \\
\text { carbon } \\
\text { content } \\
(\%)\end{array}$ & $\begin{array}{l}\text { Total } \\
\text { Nitrogen } \\
(\%)\end{array}$ & $\begin{array}{l}\mathrm{C}: \mathrm{N} \\
\text { ratio }\end{array}$ & & & & & & & & & \\
\hline & $\begin{array}{l}\text { Samplin } \\
\text { g } \\
\text { periods } \\
\text { (Days) }\end{array}$ & $\begin{array}{l}\text { Samplin } \\
\text { g } \\
\text { periods } \\
\text { (Days) }\end{array}$ & $\begin{array}{l}\text { Samplin } \\
\text { g } \\
\text { periods } \\
\text { (Days) }\end{array}$ & & & & & & & & & \\
\hline & 30 & 60 & 90 & 120 & 30 & 60 & 90 & 120 & 30 & 60 & 90 & 120 \\
\hline $\mathrm{T}_{1}$ & 36.74 & 30.70 & 27.80 & $\begin{array}{l}25.5 \\
0\end{array}$ & $\begin{array}{l}0.4 \\
5\end{array}$ & $\begin{array}{l}0.9 \\
6\end{array}$ & $\begin{array}{l}1.2 \\
1\end{array}$ & $\begin{array}{l}1.6 \\
7\end{array}$ & $\begin{array}{l}81.6 \\
4\end{array}$ & $\begin{array}{l}31.9 \\
8\end{array}$ & $\begin{array}{l}22.9 \\
8\end{array}$ & $\begin{array}{l}15.2 \\
7\end{array}$ \\
\hline $\mathrm{T}_{2}$ & 37.76 & 29.70 & 25.60 & $\begin{array}{l}22.8 \\
0\end{array}$ & $\begin{array}{l}0.5 \\
9\end{array}$ & $\begin{array}{l}1.0 \\
0\end{array}$ & $\begin{array}{l}1.1 \\
8\end{array}$ & $\begin{array}{l}1.6 \\
9\end{array}$ & $\begin{array}{l}64.0 \\
0\end{array}$ & $\begin{array}{l}29.7 \\
0\end{array}$ & $\begin{array}{l}21.6 \\
9\end{array}$ & $\begin{array}{l}13.4 \\
9\end{array}$ \\
\hline $\mathrm{T}_{3}$ & 36.21 & 30.30 & 26.90 & $\begin{array}{l}24.6 \\
0\end{array}$ & $\begin{array}{l}0.7 \\
6\end{array}$ & $\begin{array}{l}1.0 \\
9\end{array}$ & $\begin{array}{l}1.3 \\
1\end{array}$ & $\begin{array}{l}1.8 \\
7\end{array}$ & $\begin{array}{l}47.6 \\
4\end{array}$ & $\begin{array}{l}27.8 \\
0\end{array}$ & $\begin{array}{l}20.5 \\
3\end{array}$ & $\begin{array}{l}13.1 \\
6\end{array}$ \\
\hline $\mathrm{T}_{4}$ & 35.98 & 28.50 & 24.00 & $\begin{array}{l}21.1 \\
0\end{array}$ & $\begin{array}{l}0.7 \\
4\end{array}$ & $\begin{array}{l}1.0 \\
7\end{array}$ & $\begin{array}{l}1.2 \\
8\end{array}$ & $\begin{array}{l}1.7 \\
9\end{array}$ & $\begin{array}{l}48.6 \\
2\end{array}$ & $\begin{array}{l}26.6 \\
4\end{array}$ & $\begin{array}{l}18.7 \\
5\end{array}$ & $\begin{array}{l}11.7 \\
9\end{array}$ \\
\hline $\mathrm{T}_{5}$ & 37.42 & 28.90 & 24.50 & $\begin{array}{l}21.8 \\
0\end{array}$ & $\begin{array}{l}0.6 \\
4\end{array}$ & $\begin{array}{l}1.0 \\
2\end{array}$ & $\begin{array}{l}1.1 \\
9\end{array}$ & $\begin{array}{l}1.7 \\
3\end{array}$ & $\begin{array}{l}58.4 \\
7\end{array}$ & $\begin{array}{l}28.3 \\
3\end{array}$ & $\begin{array}{l}20.5 \\
9\end{array}$ & $\begin{array}{l}12.6 \\
0\end{array}$ \\
\hline
\end{tabular}

Table 3:-Changes in total phosphorus and total potassium contents during composting ofcocoa pod husk

\begin{tabular}{|c|c|c|c|c|c|c|c|c|}
\hline \multirow{3}{*}{$\begin{array}{l}\text { III. TREATMENT } \\
\mathrm{S}\end{array}$} & \multicolumn{4}{|c|}{ Total phosphorus (\%) } & \multicolumn{4}{|c|}{ Total potassium $(\%)$} \\
\hline & \multicolumn{4}{|c|}{ Sampling periods (Days) } & \multicolumn{4}{|c|}{ Sampling periods (Days) } \\
\hline & 30 & 60 & 90 & 120 & 30 & 60 & 90 & 120 \\
\hline $\mathrm{T}_{1}$ & 0.43 & 0.63 & 0.67 & 0.79 & 0.47 & 0.81 & 0.97 & 0.98 \\
\hline
\end{tabular}




\begin{tabular}{|l|l|l|l|l|l|l|l|l|}
\hline $\mathrm{T}_{2}$ & 0.59 & 0.61 & 0.66 & 0.75 & 0.62 & 0.93 & 1.18 & 1.39 \\
\hline $\mathrm{T}_{3}$ & 0.56 & 0.56 & 1.12 & 1.27 & 0.60 & 1.08 & 1.45 & 1.55 \\
\hline $\mathrm{T}_{4}$ & 0.66 & 0.69 & 0.71 & 0.73 & 0.63 & 1.05 & 1.36 & 1.44 \\
\hline $\mathrm{T}_{5}$ & 0.41 & 0.75 & 0.77 & 0.81 & 1.39 & 1.56 & 1.84 & 2.08 \\
\hline
\end{tabular}

\section{References:-}

1. Benito, M., Masaguer, A., Moliner, A., Arrigo, N. and Palma, R.M. 2003. Chemical and microbiological parameters for the characterization of the stability and maturity of pruning waste compost. Biol. Fertil. Soils, 37:184-189.

2. Bernal, M. P., Alburquerque, J. A. and Moral, R. 2009. Composting of animal manures and chemical criteria of compost maturity assessment. A review. Biores. Technol. 100: 5444-5453.

3. Bernal, M. P., C. Paredes, M. A. Sanchez and J. Cegarra. 1998. Maturity and stability parameters of composts prepared with a wide range of organic wastes. Biores. Technol., 63: 91-99.

4. Bremner, J. M. and Mulvaney, C. S. 1982. Nitrogen-total. In: Page, A.L., Miller, R.H., Keeney, D.R.(Eds.), Methods of Soil Analysis. Part 2. Chemical and Microbiological Properties. Agronomy Mono- graph No. 9. (2nd ed.). American Society of Agronomy, Madison, WI, pp. 595-622.

5. Brinton W.F., (2003). Interpretation of waste and compost Tests. J. Woods End Res. Lab., 1(4):1-6.

6. Campell A. G., Folk , R.L. and Tripepi, R.R. 1997. Wood ash as an amendment in municipal sludge and yard composting process. Compost Sci. Util., 5(1): 67-73.

7. Cardenas R. R. and Wang .K. L. 1980. Composting process, In handbook of environmental engineering. vol.II. The Human Press, New York. pp.269-327.

8. Elango D., Thinakaran, N., Panneerselvam, P., and Sivanesan, S. 2009. Thermophilic composting at municipal solid waste. Appl. Energy, 86(5): 663-668.

9. Figueira, A., J. Janick and J. N. Be Miller. 1993. New products from Theobroma cacao: Seed pulp and pod gum. In: Janick J and Simon JE (eds.), New crops. Wiley, New York. pp. 475-478.

10. Gallando, L. F. and Nogales, R. 1987. Effect of application of town refuse compost on the soil - plant system. A review. Biol. wastes, 19(1): 35-62.

11. Gaur A. C. 1982. A manual of rural composting, FAO/UNDP Regional Project RAS/75/005. Field Document No.15, FAO, Rome, Italy, p. 102.

12. Golueke, C. G. 1981. Principles of biological resources recovery. Biocycle., 22: 36-40.

13. Jackson, H. L. 1973. Soil Chemical Analysis. Prentice Hall, India Private Limited, New Delhi, pp. 183192.

14. Morel, J. L., Colin, F., Germon, J. C., Godin, P. and Juste, C. 1985. Methods for the evaluation of the maturity of municipal refuse compost. In: Gasser, J. K. R. (Ed.), composting of agricultural and other wastes. Elsevier, Applied science Publications, Barking, Essex, pp. 56-72.

15. Panse, V. G. and Sukhatme, P. V. 1961. In: Statistical methods for agricultural workers, ICAR, New Delhi. pp. 55-56.

16. Satisha, G. C. and Devaranjan, L. 2007. Effect of amendments on windrow composting of sugar industry pressmud. Waste Mgmt., 27: 1083-1091.

17. Tiquia, S. M., Tam, N. F. Y. and Hodgkiss, I. J. 1997. Effect of turning frequency on composting of spent pigmanure sawdust litter. Biores. Technol., 62: 37-42.

18. Walkely, A and I. A. Black. 1934. Determination of organic carbon in soils. Soil Sci., 37: 27-30.

19. http://www.indiastat.com/table/agriculture/2/cocoa/17443/14864/data.aspx. 